\title{
ISOLATION, IDENTIFICATION AND CHARACTERIZATION OF AZO DYE REACTIVE VIOLET 5R DEGRADING BACTERIAL STRAINS FROM THE TEXTILE SLUDGE
}

\author{
ROMANA SIDDIQUE* AND HASAN HASNAEEN AHMED
}

Department of Mathematics and Natural Sciences, BRAC University, 66 Mohakhali, Dhaka-1212

\begin{abstract}
Three bacterial strains, Streptococcus equi subsp. zooepidemicus, Brevibacillus centrosporus and Paenibacillus azoreducens, have been isolated from the sludge samples collected from Textile Industry, Bhaluka, Bangladesh, which have the abilities to degrade Reactive Violet 5R. The decolourization rate was different for the different concentrations of the same dye. Brevibacillus centrosporus displayed a decolorization rate of $94.55 \%, 90.79 \%, 91.17 \%$ when inoculated and incubated in an SM broth containing the azo dye reactive violet $5 \mathrm{R}$ at $1 \%(\mathrm{v} / \mathrm{v}), 3 \%(\mathrm{v} / \mathrm{v})$ and $5 \%$ (v/v) concentrations respectively for a consecutive 5 days. Paenibacillus azoreducens showed a decolorization rate of $85.63 \%, 86.48 \%, 38.81 \%$ for the $1 \%(\mathrm{v} / \mathrm{v}), 3 \%(\mathrm{v} / \mathrm{v})$, and $5 \%(\mathrm{v} / \mathrm{v})$ of the azo dye reactive violet $5 \mathrm{R}$ respective concentrations. On the other hand Streptococcus equi subsp zooepidemicus produced intriguing results where the decolorization rates were $67.78 \%, 21.69 \%$, $40.10 \%$ for $1 \%(\mathrm{v} / \mathrm{v}), 3 \%(\mathrm{v} / \mathrm{v})$ and $5 \%(\mathrm{v} / \mathrm{v})$ respectively of the azo dye reactive violet $5 \mathrm{R}$.
\end{abstract}

Key words: Reactive Violet 5R, Azo dye, Textile sludge

\section{INTRODUCTION}

Azo dyes account for the majorly produced synthetic dye substances in industries. They are extensively used in the textile, leather, pharmaceutical and cosmetics industries effluents, posing a threat to all life forms and environment. The chemical structure of these coloured dyes are characterized by highly substituted aromatic rings joined by one or more azo groups $(-\mathrm{N}=\mathrm{N}-)$. These substituted ring structures make these molecules recalcitrant. This is why it cannot be degradable by conventional wastewater treatment processes .One such azo dye is the Reactive Violet 5R with the chemical name trisodium; (3Z)-5-acetamido-3-[[2-hydroxy-4-(2sulfonatooxyethylsulfonyl)phenyl]hydrazinylidene]-4-oxo $-4 \mathrm{a}, 8$ adihydronaphthalene-2,7-disulfonate copper with the molecular formula, $\mathrm{C}_{20} \mathrm{H}_{16} \mathrm{~N}_{3}$ $\mathrm{Na}_{3} \mathrm{O}_{15} \mathrm{~S}_{4}$.

Improper textile dye effluent disposal in aqueous ecosystems leads to the reduction in sunlight penetration which in turn decreases photosynthetic activity, dissolved oxygen

\footnotetext{
*Corresponding author: <romanasiddique@gmail.com>.
} 
concentration, water quality and depicts acute toxic effects on aquatic flora and fauna, causing severe environmental problems worldwide (Vandevivere et al. 1998). Azo dyes also create a negative impact by causing an effect on the total organic carbon (TOC), biological oxygen demand (BOD), and chemical oxygen demand (COD) (Saratale et al. 2009;) Many synthetic azo dyes and their metabolites are toxic, carcinogenic, and mutagenic (Myslak et al. 1988).Moreover, they can cause human health disorders through direct or indirect exposure such as nausea, hemorrhage, ulceration of the skin and mucous membranes, and severe damage to kidneys, the reproductive system, liver, brain, and central nervous system.

Various physiochemical methods can be used for removal of azo dyes from wastewater. Some of these methods are effective but are quite expensive because they generate significant amounts of chemical sludge waste whose disposal in a secure landfill increases process cost. Also, there is disposal problem of such waste material to a proper place that also limit the use of these methods (Aguedach et al. 2005; Sanghi et al. 2007; Hernandez et al. 2008).

The bacterial reduction of the azo dye is usually nonspecific and bacterial decolourization is normally faster. A wide range of aerobic and anaerobic bacteria have been extensively reported as degraders of azo dyes. Some strains of aerobic bacteria use azo dyes as sole source of carbon and nitrogen (Coughlin et al. 2002); others only reduce the azo group by special oxygen-tolerant azo reductases.

The present study conducted provides substantial evidence of the efficiency of some selected organisms to decolorize the dye azo dye Reactive Violet 5R. This may eventually lead to microbial treatment of waste effluents along with the elimination of a dye's carcinogenic properties.

\section{MATERIALS AND METHODS}

\section{Sample collection}

The textile sludge samples were collected from Bhaluka, Mymensingh of Bangladesh around which many textile processing units are operating. Dyes were procured from Orient Chemicals, Bangladesh.

Isolation, Screening of dye degrading bacteria

The Reactive Violet 5R azo dye was inoculated with the sludge sample via SM broth media consists of glucose ( $1 \mathrm{~g} / \mathrm{liter})$, peptone $(10 \mathrm{~g} / \mathrm{liter})$, yeast extract $(1 \mathrm{~g} / \mathrm{liter})$ potassium dihydrogen phosphate $(1.9 \mathrm{~g} /$ liter $)$ dipotassium hydrogen phosphate $(0.6 \mathrm{~g} / \mathrm{liter})$ at a temperature of 37 degrees Celsius. The $\mathrm{pH}$ levels varied from 6.9 to 7.1. Each flask contained $200 \mathrm{~mL}$ autoclaved SM broth and the dye reactive violet $5 \mathrm{R}$ was added at 3 
different concentrations, $1 \%(\mathrm{v} / \mathrm{v}), 5 \%(\mathrm{v} / \mathrm{v})$ and $10 \%(\mathrm{v} / \mathrm{v})$. The flasks were incubated at $37^{\circ} \mathrm{C}$ under static condition. Absorbance reading was taken with the help of a spectrophotometer (UVmini-1240V) for five consecutive days at $410 \mathrm{~nm}$ and presence of microbial activity was confirmed after the decolourization of dyes.

After incubation, cell suspensions from each flask were plated onto SM agar medium and incubated at $37^{\circ} \mathrm{C}$ for $24 \mathrm{~h}$. After that a screening procedure was carried out judging by the size and morphological characteristics of the colonies. About 20 actively growing colonies were selected for purification. Selected isolates were enriched by Nutrient Agar broth and purified by streaking on nutrient agar medium. The purified cultures were preserved to determine the genus of the microorganisms present in the sample and for subsequent study.

Screening was done to find out the efficient bacterial strains capable of decolorizing the Reactive Violate 5R. For this purpose, eight isolates having the ability to decolorize RV 5R from all samples were selected. After the decolourization, ability of each isolate was tested in the liquid medium. Media inoculated with the respective inocula were incubated at $37^{\circ} \mathrm{C}$ for $120 \mathrm{~h}$. Then absorbance reading was executed using spectrophotometer at $410 \mathrm{~nm}$. The lower the absorbance higher the dye degradation rate. Uninoculated blanks were run to determine abiotic decolourization. The eight most effective bacterial isolates (B1, B2, B3, B4, B5, B6, B7, and B8) were characterized by using different biochemical test (Table 1) and ABIS (Advanced Bacterial Identification Software) microbiology software which is a laboratory tool for bacterial identification was used to justify and determine the identity of these bacteria (Table 2).

\section{Measurement of Decolourization}

The three most effective bacterial isolates (B1, B4, B8) from the final screening were further examined for their decolourization potentials in conical flasks after $120 \mathrm{~h}$ at different dye (RV 5R) concentrations (1\%,3\% and 5\%).The medium was inoculated with the respective bacterial strain by adding inocula of uniform cell density (OD:0.6) at 410 $\mathrm{nm}$. The conical flasks were incubated at $37^{\circ} \mathrm{C}$ under static conditions. Uninoculated test tubes with SM media containing azo dye were incubated under similar conditions to check for abiotic decolourization dye. Decolourization was measured after 24h, 48h, 72h, $96 \mathrm{~h}$ and $120 \mathrm{~h}$ at $410 \mathrm{~nm}$ and the percentage of decolourization was estimated based on the reduction in absorbance.

The dye degradation efficiency of bacterial isolates was calculated by the following equation.

$$
\text { De-colorization }(\%)=[\mathrm{I}-\mathrm{F}] \times 100 / \mathrm{I}
$$

Where, $\mathrm{I}=$ initial absorbance; $\mathrm{F}$ = final absorbance of decolorized medium. 


\section{RESULTS}

\section{Biochemical Tests}

Biochemical tests were done to detect and confirm the presence of microorganisms after the observation of the single isolated colonies. Several biochemical tests were done among them were Gram staining, Starch hydrolysis, TSI test, Simmon's citrate test, Oxidase test, Catalase test, Nitrate reduction, Nitrate Broth media, MRVP, Indole test and Urease test.

Table 1: Morphological and biochemical characteristics of bacterial isolates obtained from the textile sludge.

\begin{tabular}{|c|c|c|c|c|c|c|c|c|c|c|c|c|c|c|c|c|}
\hline \multirow[b]{2}{*}{$\begin{array}{l}\stackrel{8}{g} \\
\stackrel{0}{\tilde{\sigma}} \\
\stackrel{0}{0}\end{array}$} & \multirow{2}{*}{ 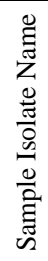 } & \multicolumn{2}{|c|}{$\begin{array}{l}\text { Gram } \\
\text { stain }\end{array}$} & \multicolumn{3}{|c|}{ MIU } & \multirow[b]{2}{*}{ 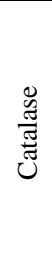 } & \multirow[b]{2}{*}{$\begin{array}{l}0 \\
\frac{\tilde{J}}{\tilde{J}} \\
\frac{\pi}{\pi} \\
0\end{array}$} & \multirow{2}{*}{ 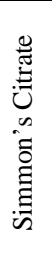 } & \multirow[b]{2}{*}{$\stackrel{\mathscr{z}}{\Sigma}$} & \multirow[b]{2}{*}{ 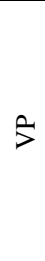 } & \multicolumn{2}{|c|}{$\begin{array}{c}\text { Triple sugar } \\
\text { iron test }\end{array}$} & \multirow{2}{*}{ 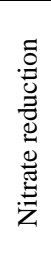 } & \multirow{2}{*}{ 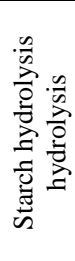 } & \multirow[t]{2}{*}{$\begin{array}{c}\text { Presumptive } \\
\text { Organism }\end{array}$} \\
\hline & & $+/-$ & 总 & 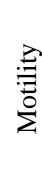 & $\begin{array}{l}\frac{0}{0} \\
\stackrel{\Xi}{\Xi}\end{array}$ & 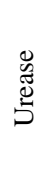 & & & & & & Gas & $\mathrm{H}_{2} \mathrm{~S}$ & & & \\
\hline 1. & B1 & + & rod & + & - & - & + & - & + & - & - & - & + & - & - & Brevibacillus sp. \\
\hline 2. & B2 & + & rod & + & - & - & - & - & - & - & - & - & - & + & + & Bacillus sp. \\
\hline 3. & B3 & + & rod & + & - & - & + & - & + & - & - & - & - & - & + & Bacillus sp. \\
\hline 4. & B4 & - & rod & - & - & - & - & - & - & - & - & - & - & - & + & Paenibacillus sp. \\
\hline 5. & B5 & + & rod & + & - & - & + & - & - & - & - & - & - & - & - & Bacillus sp. \\
\hline 6. & B6 & + & rod & + & - & - & + & - & - & - & - & - & - & + & + & Bacillus sp. \\
\hline 7. & B7 & + & rod & + & - & - & + & - & - & - & - & - & - & - & + & Bacillus sp. \\
\hline 8. & B8 & + & cocci & - & - & + & + & - & - & - & - & - & - & + & + & Streptococcus sp. \\
\hline
\end{tabular}

$+=$ Positive reaction; - = Negative reaction

Table 2: Identification of Bacterial strain Using ABIS software (http://www.tgw1916.net/ bacteria_logare_desktop.html)

\begin{tabular}{lll}
\hline Sample no & Isolate name & Presumptive organism detected by ABIS software \\
\hline 1. & B1 & Brevibacillus laterosporus \\
2. & B2 & Bacillus firmus \\
3. & B3 & Bacillus megaterium \\
4. & B4 & Paenibacillus azoreducens \\
5. & B5 & Bacillus Nealsonii \\
6. & B6 & Bacillus firmus \\
7. & B7 & Bacillus simplex \\
8. & B8 & Streptococcus equi subsp. zooepidemicus \\
\hline
\end{tabular}




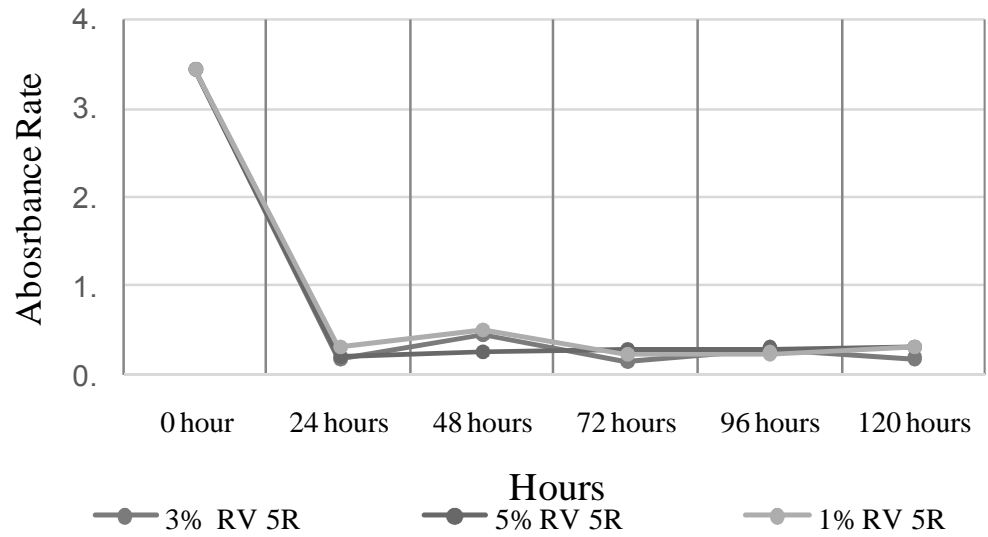

Fig.1. Absorbance rates of $1 \%(\mathrm{v} / \mathrm{v}), 3 \%(\mathrm{v} / \mathrm{v}), 5 \%(\mathrm{v} / \mathrm{v})$ of the azo dye reactive violet $5 \mathrm{R}$ decolorized by organism (B1) (Brevibacillus centrosporus).

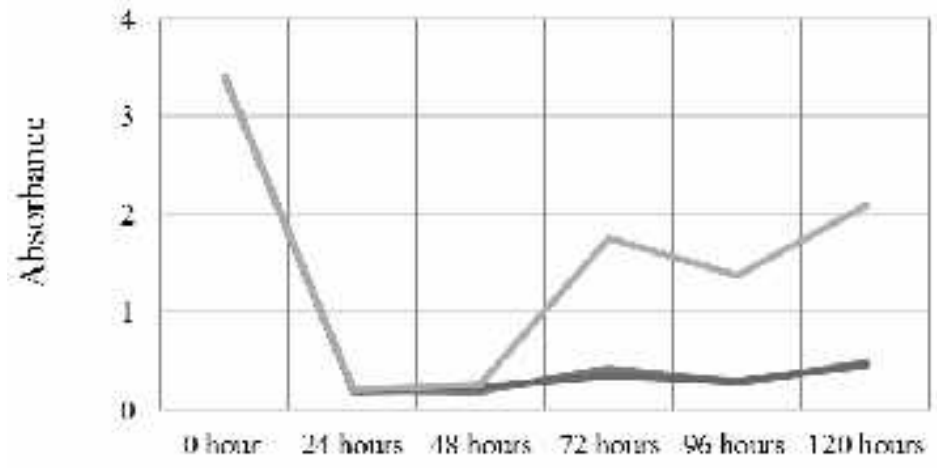

llours

- $1 \%$ RV 5R $3 \%$ RV 5R $-5 \%$ RV 5R

Fig. 2. Absorbance rates of $1 \%(\mathrm{v} / \mathrm{v}), 3 \%(\mathrm{v} / \mathrm{v}), 5 \%(\mathrm{v} / \mathrm{v})$ of the azo dye reactive violet $5 \mathrm{R}$ decolorized by the organism (B4) (Paenibacillus azoreducens).

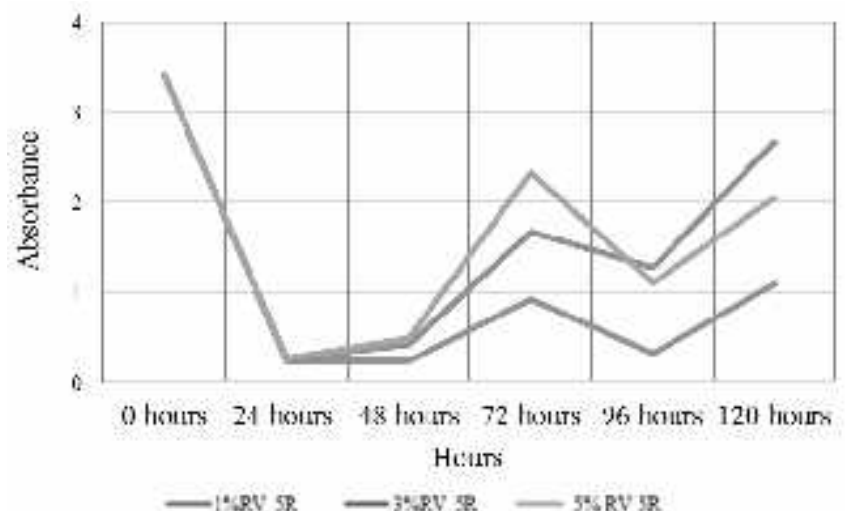

Fig. 3. Absorbane rates of $1 \%(\mathrm{v} / \mathrm{v}), 3 \%(\mathrm{v} / \mathrm{v}), 5 \%(\mathrm{v} / \mathrm{v})$ of the azo dye reactive violet $5 \mathrm{R}$ decolorized by the organism (B8) Streptococcus equi subsp. zooepidemicus. 
Table 3: Percentage of decolourization of RV 5R by different bacterial isolates at different concentration in SM media after $120 \mathrm{~h}$.

\begin{tabular}{cccc}
\hline $\begin{array}{c}\text { Concentration } \\
\text { of RV 5R (v/v) }\end{array}$ & $\begin{array}{c}\text { \% of Decolourization } \\
\text { by Brevibacillus } \\
\text { centrosporus }\end{array}$ & $\begin{array}{c}\text { \% of Decolourization } \\
\text { by Paenibacillus } \\
\text { azoreducens }\end{array}$ & $\begin{array}{c}\text { \% of Decolourization by } \\
\text { Streptococcus equi }\end{array}$ \\
\hline $1 \%$ & $94.55 \%$ & $85.63 \%$ & $67.78 \%$ \\
$3 \%$ & $90.79 \%$ & $86.48 \%$ & $21.69 \%$ \\
$5 \%$ & $91.17 \%$ & $38.81 \%$ & $40.10 \%$ \\
\hline
\end{tabular}

\section{DISCUSSION}

Different micro-organisms react differently to the same dye. The decolourization performance of Reactive Violet 5R by the Paracoccus sp. GSM2 was estimated by increasing initial dye concentration (100-800 $\mathrm{mg} / \mathrm{L}) . \mathrm{It}$ was observed that the percentage of decolourization was decreased slowly with increasing dye concentration (Bheemaraddi et al. 2014). In a study conducted, three different bacterial strains were isolated from the textile dye effluent. Based on preliminary tests, plating on selective media and biochemical tests, they were identified as Bacillus sp. Escherichia coli and Pseudomonas fluorescens. (Olukanni et al. 2005)

There were also experiments concluding to the analysis which showed that the Staphylococcus aureus, Bacterioides fragilis, Bacillus subtilis, Bacillus cereus, Clostridium perifringens, Escherichia coli and Peptostreptococcus sp. can reduce and stabilize textile effluents containing predominantly Indigo Blue. (Olukanni et al. 2005)

In this study, Brevibacillus centrosporus showed the highest decolorization rates of $94.55 \%, 90.79 \%$, and $91.17 \%$ when inoculated and incubated for 5 consecutive days in SM broth media containing dye reactive violet $5 \mathrm{R}$ at the concentrations of $1 \%(\mathrm{v} / \mathrm{v}), 3 \%(\mathrm{v} / \mathrm{v})$, and $5 \%(\mathrm{v} / \mathrm{v})$ respectively (Fig.1 \& Table 3). In the same way Paenibacillus azoreducens showed a decolorization rate of $85.63 \%, 86.48 \%$ and $38.81 \%$ when inoculated and incubated for 5 consecutive days in SM broth containing the reactive violet $5 \mathrm{R}$ at the concentrations of $1 \%$ $(\mathrm{v} / \mathrm{v}), 3 \%(\mathrm{v} / \mathrm{v})$, and 5\% (v/v) respectively (Fig.2 \& Table 3). However, Streptococcus equi subsp. zooepidemicus showed the highest growth rate for which the absorbance rate was much higher than compared to the other two bacterial strains but this led to a significant decrease in the decolorization rate which was $67.78 \%, 21.69 \%$ and $40.10 \%$ when inoculated and incubated in SM broth containing reactive violet $5 \mathrm{R}$ at the concentrations of $1 \%(\mathrm{v} / \mathrm{v}), 3 \%(\mathrm{v} / \mathrm{v})$ and 5\%(v/v) respectively (Fig. 3 \& Table 3). Bacillus simplex, Bacillus firmus, Bacillus megaterium and Bacillus nealsonii, these microbial strains also partially decolorized the azo dye reactive violet $5 \mathrm{R}$. It is reported that mixed bacterial culture can give a better degradation rate than the individual strain. (Chen et al. 2003)

There is a difference between each and every organisms' decolourization rates and growth rates when it comes to being inoculated and incubated in a specific type of azo dye. This difference arises due to the physiological and morphological characteristics of the microbes. The chemical properties of the dye is also a significant factor and the type of the microbe also plays a major role in this case. 
The use of microorganisms like bacteria and fungi for the removal of synthetic dyes from industrial effluent offer considerable advantages. This study itself seems to indicate that microbial method is environmentally stable and economically efficient. The only problem lies with the isolation of the proper strain of microbes from its native environment. Their commercial use can become a revolutionizing weapon for the decolourization of the synthetic dyes polluting the environment. Textile sludge can be controlled and their carcinogenic effects can be brought to a minimum. In general, bioremediation will become a strong approach for controlling the water pollution.

\section{ACKNOLEDGEMENTS}

This study was supported by the Department of Mathematics and Natural Sciences, BRAC University. The research was carried out at Microbiology and Biotechnology laboratory of the university.

\section{REFERENCES}

Aguedach, A., S. Brosillon, J. Morvan and E. K. Lhadi. 2005. Photocatalytic degradation of azodyes reactive Black 5 and Reactive Yellow 145 in water over a newly deposited titanium dioxide. Applied Catalysis B: Environmental 57: 55-62.

Bheemaraddi, M. C., Patil, S., Shivannavar, C. T., \& Gaddad, S. M. (2014). Isolation and Characterization of Paracoccus sp. GSM2 Capable of Degrading Textile Azo Dye Reactive Violet 5. The Scientific World Journal, 2014, 410704. http://doi.org/10.1155/2014/410704

Chen, K.C., J.Y. Wu, D.J. Liou and S.C.J. Hwang. 2003. Decolorization of the textile dyes by newly isolated bacterial strains. Journal of Biotechnology 10: 57-68.

Coughlin, M.F., B.K. Kinkle and P.L. Bishop. 2002 Degradation of acid orange 7 in an aerobic biofilm. Chemosphere, 46: 11-19

Hernandez, J.M.P., M.V. Yunny, F.J. Rodríguez, T.W. Chapman, M.I. Maldonado and L.A. Godínez. 2008. Comparison of hydrogen peroxide-based processes for treating dye-containing wastewater: decolorization and destruction of Orange II azo dye in dilute solution.Dyes Pigments 76: 656-662.

Mallikarjun, C. Bheemaraddi, Santosh Patil and T. Channappa. 2014. Shivannavar and Subhashchandra M. Gaddad Scientific World Journal. 2014: 410704.

Myslak, ZW and HM Bolt. 1988. Occupational exposure to azo dyes and risk of bladder cancer. ZblArbeitsmed. 38: 310-321.

Olukanni, O.D., A.A. Osuntoki and G.D. Gbenle. 2005. Textile effluent biodegradation potentials of textile effluent-adopted and non-adopted bacteria. Applied Environmental Microbiology, pp: 837-844.

Sanghi, R., B. Bhattacharya and V. Singh. 2007. Seed gum polysaccharides and their grafted copolymers for the effective coagulation of textile dye solutions. Reactive and Functional Polymers 67: 495-502.

Saratale, RG, GD Saratale, DC Kalyani, JS Chang and SP Govindwar. 2009. Enhanced decolorization and biodegradation of textile azo dye Scarlet $\mathrm{R}$ by using developed microbial consortium-GR. Bioresource Technology. 100(9): 2493-2500.

Vandevivere, PC, R Bianchi and W Verstraete. 1998. Treatment and reuse of wastewater from the textile wet-processing Industry: review of emerging technologies. Journal of Chemical Technology and Biotechnology. 72: 289-302. 